\title{
Granulocyte macrophage-colony stimulating factor and interleukin-3 increase expression of type II tumour necrosis factor receptor, increasing susceptibility to tumour necrosis factor-induced apoptosis. Control of leukaemia cell life/death switching
}

\author{
C Rae ${ }^{1}$ and DJ MacEwan ${ }^{*, 1}$ \\ ${ }^{1}$ Department of Biomedical Sciences, Institute of Medical Sciences, University \\ of Aberdeen, Foresterhill, Aberdeen, UK \\ * Corresponding author: DJ MacEwan, Department of Biomedical Sciences, \\ Institute of Medical Sciences, University of Aberdeen, Foresterhill, Aberdeen, \\ UK. Tel: + 44-(0)-1224-555762; Fax: + 44-(0)-1224-555719; \\ E-mail: david.macewan@abdn.ac.uk
}

Received 06.4.04; revised 12.7.04; accepted 13.7.04; published online 1.10.04 Edited by M Miura

\begin{abstract}
Tumour necrosis factor (TNF) induces apoptosis in a range of cell types via its two receptors, TNFR1 and TNFR2. Here, we demonstrate that proliferation and TNFR2 expression was increased in human leukaemic TF-1 cells by granulocyte macrophage-colony stimulating factor (GM-CSF) and interleukin-3 (IL-3), with TNFR1 expression unaffected. Consequently, they switch from a proliferative to a TNF-induced apoptotic phenotype. Raised TNFR2 expression and susceptibility to TNF-induced apoptosis was not a general effect of proliferation as IL-1 $\beta$ and IFN- $\gamma$ both proliferated TF- 1 cells with no effect on TNFR expression or apoptosis. Although raised TNFR2 expression correlated with the apoptotic phenotype, stimulation of apoptosis in GM-CSF-pretreated cells was mediated by TNFR1, with stimulation of TNFR2 alone insufficient to initiate cell death. However, TNFR2 did play a role in apoptotic and proliferative responses as they were blocked by the presence of an antagonistic TNFR2 antibody. Additionally, coincubation with cycloheximide blocked the mitotic effects of GM-CSF or IL-3, allowing only the apoptotic responses of TNF to persist. TNF life/death was also observed in K562, but not MOLT-4 and HL-60 human leukaemic cell types. These findings show a cooperative role of TNFR2 in the TNF life/death switching phenomenon.

Cell Death and Differentiation (2004) 11, S162-S171.

doi:10.1038/sj.cdd. 4401494

Published online 1 October 2004
\end{abstract}

Keywords: cancer cells; cytokine; tumour necrosis factor- $\alpha$; receptor; apoptosis

Abbreviations: FACS, fluorescence-activated cell sorting; FBS, foetal bovine serum; GM-CSF, granulocyte macrophage-colony stimulating factor; IFN, interferon; IL, interleukin; NF- $\kappa \mathrm{B}$, nuclear factor- $\kappa \mathrm{B}$; PARP, poly(ADP-ribose) polymerase; PBS, phosphatebuffered saline; TNF, tumour necrosis factor- $\alpha$; TNFR, TNF receptor

\section{Introduction}

Tumour necrosis factor- $\alpha$ (TNF) cytokine is produced mainly by activated macrophages and monocytes. ${ }^{1}$ Although TNF was first recognised for its ability to induce haemorrhagic necrosis of certain tumours, ${ }^{2}$ it also mediates a variety of other physiological responses, including differentiation, inflammation and proliferation as well as apoptotic and necrotic cell death. ${ }^{3}$ TNF also produces the systemic effects of fever and cachexia. ${ }^{4}$

TNF mediates its actions by binding to distinct cell surface receptor types, Tumour necrosis factor receptor (TNFR) 1 (p55TNFR or CD120a) and TNFR2 (p75TNFR or CD120b), ${ }^{5}$ and the existence of two receptor subtypes may partially explain the disparity of TNF-induced effects. ${ }^{6}$ Human TNFR1 and TNFR2 extracellular domains share $28 \%$ identity, while there is a complete absence of homology between the intracellular domains of the two TNFRs. ${ }^{7}$ The two receptor subtypes mediate their effects on cells through distinct signalling pathways. The relative surface expression of these two TNF receptors can affect the cellular responses to TNF stimulation and this can be altered by the growth state or metabolic activity of the cell. ${ }^{5,8} \mathrm{~A}$ variety of agents have been tested with regard to their ability to alter the level of TNFRs, and subsequently alter the effects of TNF. ${ }^{9-12}$

Apoptosis (programmed cell death) plays an important role in the homeostasis and development of all tissues within an organism. Apoptosis can be initiated by a variety of stimuli including growth factor withdrawal, ultraviolet- or $\gamma$-irradiation and many chemotherapeutic drugs. ${ }^{13}$ In contrast to necrosis, apoptosis is a well-regulated physiological process which is characterised by macromolecular breakdown and cellular fragmentation. ${ }^{14}$ Fragmentation of apoptotic cells into membrane-bound apoptotic bodies and membrane changes eventually leads to phagocytosis of the affected cell. ${ }^{15}$

TNF may act as a negative regulator of haematopoiesis to directly suppress proliferation by inducing apoptosis. ${ }^{16}$ This effect is primarily mediated by signalling through TNFR $1^{17,18}$ which is essential for regulating haematopoiesis. ${ }^{19,20}$ The majority of TNF-induced nuclear factor- $\kappa \mathrm{B}$ (NF- $\kappa \mathrm{B}$ ) activation, ${ }^{21}$ growth inhibition and suppression of proliferation also resulted exclusively from activation of TNFR $1 .{ }^{22}$ Although TNF has a cytotoxic or cytostatic effect when tested with various malignant cell lines, clinical trials in cancer patients have revealed high systemic toxicity of TNF. ${ }^{23,24}$ It is at present unclear which of the receptors are responsible for the various effects of TNF, although TNFR1 appears to be the predominant receptor that signals both cytotoxic and inflammatory responses. ${ }^{25}$ Therefore, agents which act selectively on TNFR2 may be without some of the side effects 
of TNF in cancer treatment, which at present limit its effectiveness.

Granulocyte macrophage-colony stimulating factor (GMCSF) and interleukin-3 (IL-3) are two haemopoietic growth factors that significantly contribute to the regulation of haemopoietic progenitor cell proliferation and differentiation. ${ }^{26,27}$ Previous studies using these cytokines, before and during chemotherapy to recruit leukaemia cells into cell cycle, and thus make them more susceptible to chemotherapy, have revealed no benefit. ${ }^{28}$ However, with the findings that certain conditions can increase the expression of TNFR2, ${ }^{8}$ this may represent a possible mechanism with which to increase susceptibility to TNF-induced apoptosis, while avoiding some of the deleterious side effects of TNF. In this study, we investigated the effects of cytokines on the levels of TNFR expression and the effect these cytokines have on the relative susceptibility of TF-1 cells to TNF-induced apoptosis. We compare the apoptotic and proliferative effects of agents selective in TNFR subtype activation, and report novel modulation and exchange between TNF-driven cytotoxicity or TNF-induced proliferation (TNF life/death switching).

\section{Results}

\section{Cytokine control of TNF life/death switching of TF-1 cells}

Our previous work on TF-1 cells uncovered a novel TNF life/ death switching phenomenon that see the same leukaemic cell switch from their normally proliferative state upon TNF treatment to a TNF-responsive apoptotic phenotype, dependent on the mitotic condition of the cell. ${ }^{8}$ Here, we show that GM-CSF and IL-3 pretreatment can switch TF-1 cells from a TNF proliferative- to a TNF apoptotic phenotype. When GMCSF or IL-3 was added to TF-1 cells, a large increase in total cell number was observed (Figure 1a). TNF in itself is mildly proliferative too to normal TF-1 cell (Figure 1a). This proliferative effect is seen in untreated cells, which respond to TNF by becoming mitotic (Figure 1b). However, pretreatment of TF-1 cells with GM-CSF (Figure 1b) and IL-3 (not shown) switched these cells into an apoptotic phenotype when stimulated with TNF. Thus, the same cell responds to TNF with either proliferation or apoptosis, and which is brought about by GM-CSF and IL-3. Addition of TNF to proliferating TF- 1 cells (precultured in GM-CSF-containing medium) caused a concentration-dependent increase in the number of cells in the hypodiploid region after propidium iodide staining (Figure 2a) and an increase in Annexin-V binding to membrane-exposed phosphatidylserine (Figure $2 b$ ) - both indicators of apoptosis - as well as the observed decrease in overall mitochondrial health, an indicator of cell viability and cell number measured by the MTS assay (Figure 1b).

In quiescent cells, TNF (10 $\mathrm{ng} / \mathrm{ml})$ caused a slight increase in apoptosis, whereas GM-CSF $(0.1 \mathrm{ng} / \mathrm{ml})$ and IL-3 $(10 \mathrm{ng} /$ $\mathrm{ml}$ ) were antiapoptotic (Figure $3 a$ and b). However, coincubation of cells with TNF and either GM-CSF or IL-3 increased TF-1 cell susceptibility to TNF-induced apoptosis (observed as an increase in the hypodiploid peak with propidium iodide staining). These observations were confirmed by an increase
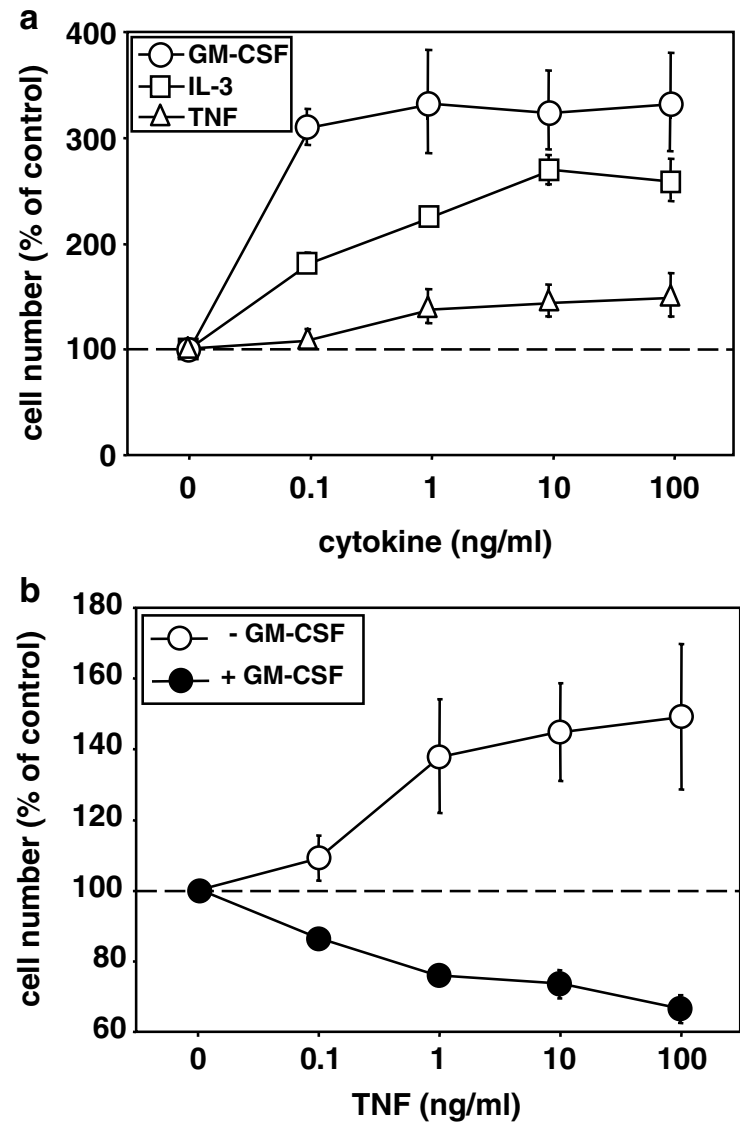

Figure 1 Effect of cytokines on TF-1 cells. Cell number was measured using the MTS assay, which measures metabolic activity of cells. Cells were cultured and treated for $24 \mathrm{~h}$ as described in Materials and Methods. (a) Cells were cultured with the indicated concentration of GM-CSF, IL-3 or TNF for $24 \mathrm{~h}$. All three cytokines caused proliferation of the quiescent cells with GM-CSF and IL-3 having the greatest effect. (b) TNF was toxic to proliferating cells (cultured in media containing $0.1 \mathrm{ng} / \mathrm{ml}$ GM-CSF), whereas proliferation was induced in quiescent cells (cultured in medium without GM-CSF). The effect of TNF at the indicated concentration was measured after $24 \mathrm{~h}$ incubation. The results illustrate a representative experiment of at least three others with similar findings, showing mean + S.D. values of quadruplicate samples

in the levels of poly(ADP-ribose) polymerase (PARP) fragment present in these apoptotic cells (Figure $3 c$ and d). PARP DNA repair enzyme is cleaved in a caspase-dependent manner and is a good indicator of apoptosis.

\section{Role of TNFRs}

TF-1 cells cultured in GM-CSF-free medium expressed similar levels of TNFR1 and TNFR2 (Figure 4a). The surface expression of TNFR2 on TF-1 cells was increased by addition of GM-CSF or IL-3 to the culture media (Figures $4 \mathrm{~b}$ and $\mathrm{c}$ ). Addition of both growth factors together had no additional increase above the individual effects (data not shown). Neither GM-CSF nor IL-3 - added alone or together - had any effect on the expression of TNFR1 (data not shown). Thus, the proliferative effects of GM-CSF and IL-3 lead to an increased expression of TNFR2, which may be responsible for the switching into an apoptotic phenotype rather than a 

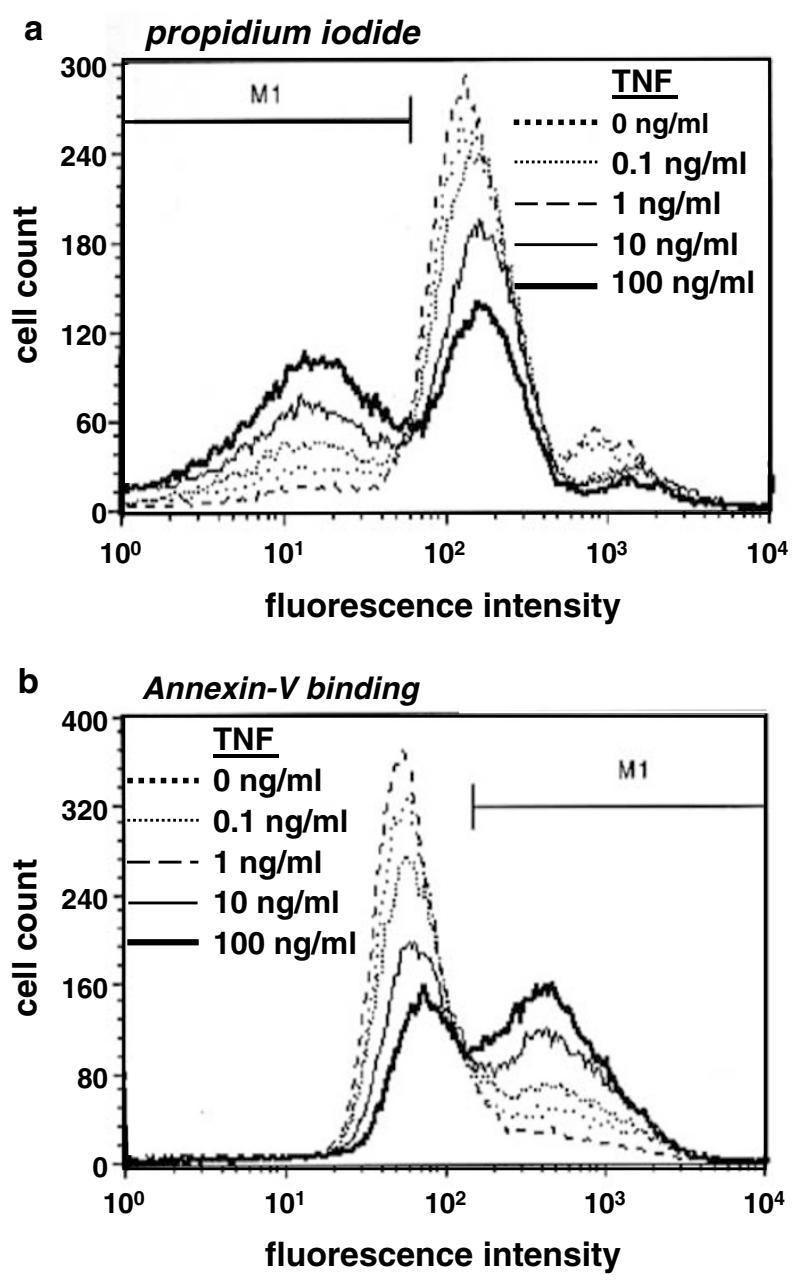

Figure 2 Effect of TNF on TF-1 cell apoptosis. Proliferating cells were cultured and treated with TNF for $24 \mathrm{~h}$ before (a) staining with propidium iodide and measuring cells within the hypodiploid region and (b) measuring Annexin-V binding as described in Materials and Methods. Data are from a representative independent experiment performed at least two other times with similar findings

proliferative phenotype. However, not all growth factors increased the expression of TNFR2 on TF-1 cells as neither interleukin- $\beta$ (IL-1 $\beta)$ nor interferon- $\gamma($ IFN- $\gamma$ ) had any effect on TNFR2 (Figure $5 a$ and b). Both of these cytokines did, however, have a proliferative and antiapoptotic effect on quiescent cells (Figure $5 c$ and d). Unlike GM-CSF and IL-3, IL-1 $\beta$ and IFN- $\gamma$ did not appear to increase susceptibility of TF-1 cells to TNF-induced apoptosis (Figure $5 \mathrm{~d}$ ). Thus, proliferation of TF-1 cells in itself is not sufficient to cause apoptotic effects of TNF, but requires increased expression of TNFR2 for the cytotoxic effects of TNF to become apparent.

As the increased expression levels of TNFR2 could be responsible for the increased susceptibility to TNF-induce apoptosis, we examined the effects of the TNFR-selective muteins, R1-TNF and R2-TNF, which bind selectively to TNFR1 and TNFR2, respectively. In GM-CSF-pretreated TF1 cells, R1-TNF caused a similar concentration-dependent increase in apoptosis and cytotoxicity to wild-type TNF, whereas R2-TNF had little or no effect on either apoptosis or toxicity of proliferating cells (Figure 6). This is surprising
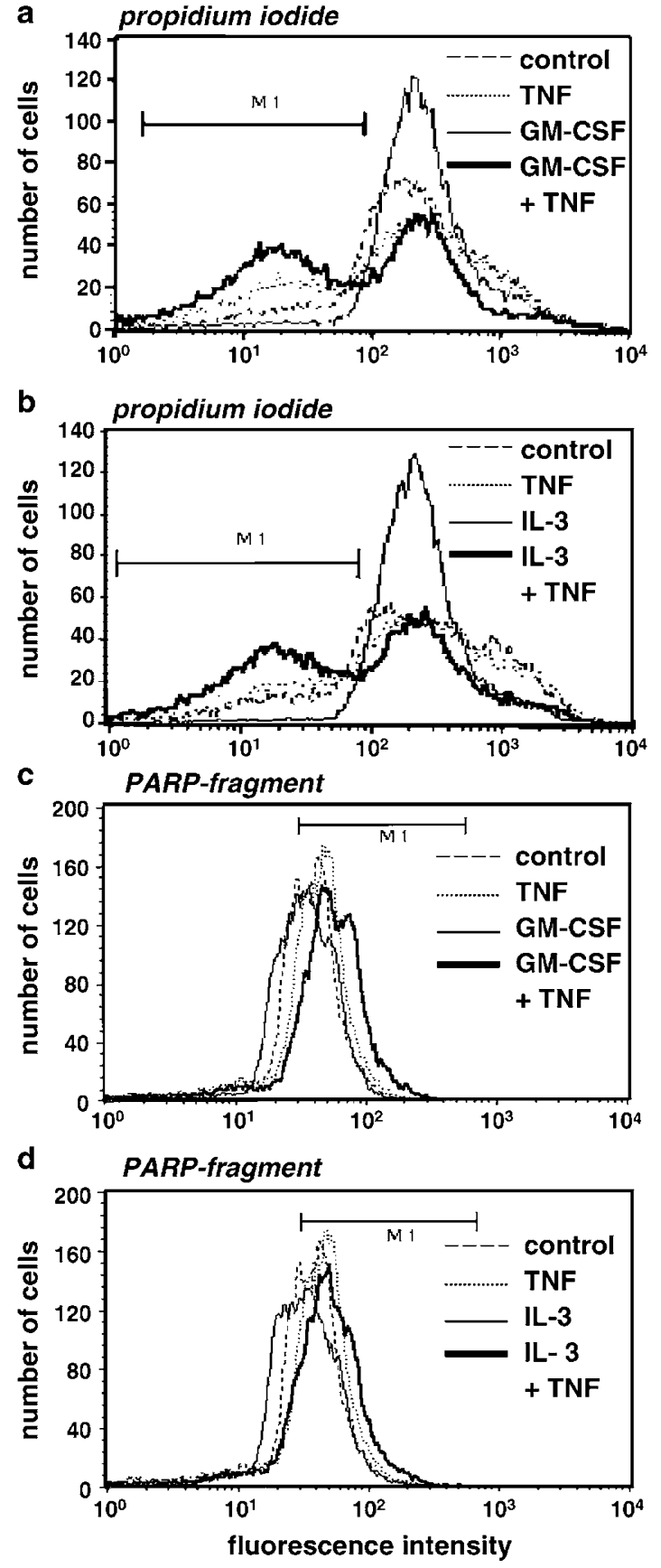

Figure 3 Effect of cytokines on apoptosis of TF-1 cells. Cells were cultured in medium without GM-CSF and treated for $24 \mathrm{~h}$ with combinations of cytokines. Apoptosis was measured $(\mathbf{a}, \mathbf{b})$ by cells in the M1 (hypodiploid) region after propidium iodide staining and (c, d) by cellular immunofluorescence measurement of the cleaved $85 \mathrm{kDa}$ PARP fragment. Cells in the M1 region for (a) and (b)

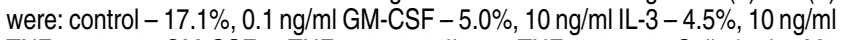
TNF $-31.3 \%$, GM-CSF + TNF $-49.4 \%$, IL-3 + TNF $-48.7 \%$. Cells in the M1 region for (c) and (d) were: control - 62.8\%, $0.1 \mathrm{ng} / \mathrm{ml} \mathrm{GM-CSF}-57.6 \%, 10 \mathrm{ng} /$ $\mathrm{ml} \mathrm{IL-3} \mathrm{-} \mathrm{52.9 \% ,} 10 \mathrm{ng} / \mathrm{ml}$ TNF - 74.8\%, GM-CSF + TNF - 81.9\%, IL-3 + TNF $76.3 \%$. Data are from a representative independent experiment performed at least two other times with similar findings

given that TNFR1 expression remains unchanged, but increases in TNFR2 levels correlate with increased TNFinduced apoptosis. We also observed that addition of R1-TNF 
a

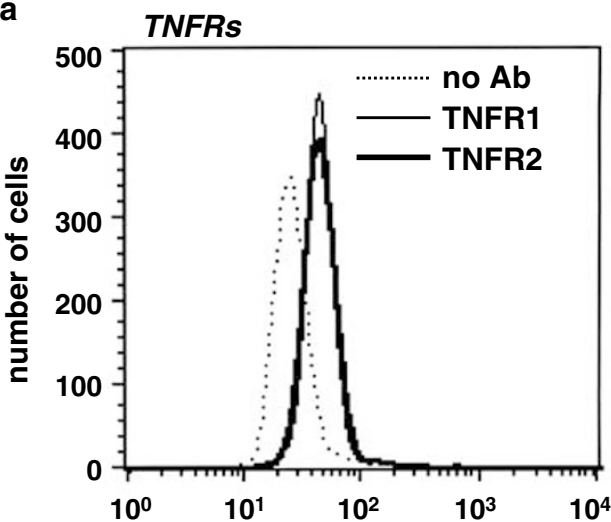

b

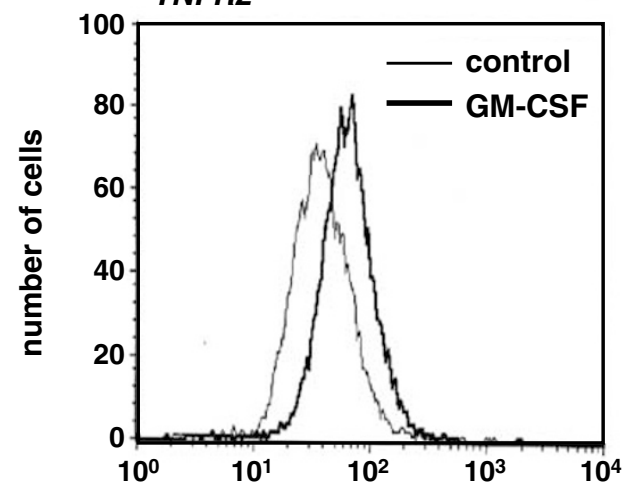

C

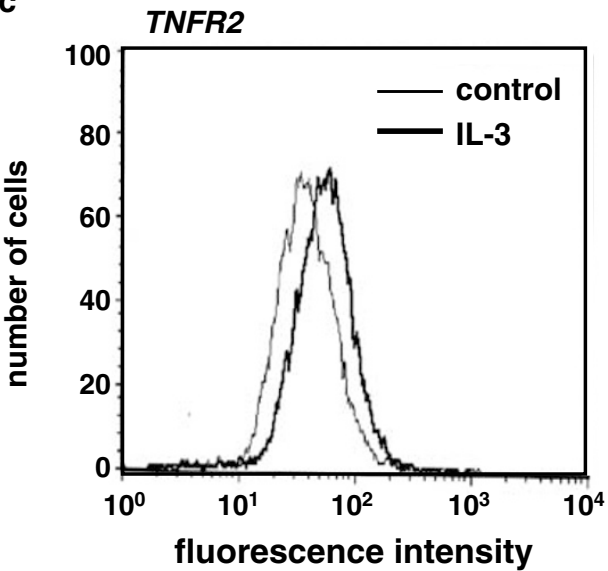

Figure 4 TNFR levels of TF- 1 cells treated with GM-CSF and IL-3. TNFR levels of TF-1 cells were measured using monoclonal antibodies to TNFR1 (htr-1) and TNFR2 (utr-9). (a) Cells cultured in medium without GM-CSF had similar levels of TNFR1 and TNFR2. A control antibody (mitogen-activated protein kinase, Santa Cruz Biotechnology) gave the same results as no antibody (Ab). Addition of (b $0.1 \mathrm{ng} / \mathrm{ml} \mathrm{GM}-\mathrm{CSF}$ or (c) $10 \mathrm{ng} / \mathrm{ml} \mathrm{IL-3}$ for $24 \mathrm{~h}$ increased the surface expression of TNFR2. Data are from a representative independent experiment performed at least two other times with similar findings

and R2-TNF together had no increase in effects above R1TNF or wild-type TNF alone (data not shown).

\section{Control of life/death switching by cycloheximide}

Although addition of GM-CSF or IL-3 increased the susceptibility of TF-1 cells to TNF-induced apoptosis, the proliferative effect of these cytokines predominated and resulted in an increase in total cell number even in the presence of TNF (Figure 7). In order to overcome the proliferative effect of the growth factors, the cells were treated with the protein translation inhibitor cycloheximide in addition to growth factors and TNF. Cycloheximide alone had no effect on the expression of TNFR2 (data not shown) and did not affect the increase in TNFR2 expression caused by GM-CSF or IL-3 (Figures 8a and b). Moreover, cycloheximide added alone had no effect on quiescent cells, but decreased the total cell number in the proliferating cells (Figure $8 \mathrm{c}$ ). Cycloheximide $(1 \mu \mathrm{g} / \mathrm{ml})$ almost totally abolished the proliferative effect of the cytokines and caused a toxic effect when added in conjunction with TNF (Figure 7). However, addition of GM-CSF or IL-3 plus TNF and cycloheximide showed no increase in toxicity above TNF and cycloheximide added together (Figure 7). Thus, cycloheximide blocks the proliferative effects of GMCSF and IL-3 and switches TNF into a more cytotoxic agent, probably by still allowing increased levels of TNFR2 to develop in treated TF-1 cells.

\section{TNF life/death switching in other human leukaemia cells}

We tested other types of human leukaemia cells to observe whether they also underwent switching from a proliferative to a cytotoxic phenotype under the control of GM-CSF. As can be seen in Figure 9, TF-1 cells, K562 human chronic myelogenous leukaemia cells, also undergo TNF life/death switching in a GM-CSF-dependent manner (Figure 9a and b), although the level of TNF-induced effects in K562 cells is less that those observed in TF-1 cells. However, in comparison MOLT-4 human acute T-lymphocytic leukaemia cells and HL-60 human promyelocytic leukaemia cells only display TNF-induced cell death in response to TNF (Figure 9c and d). The effect of an anti-GM-CSF antisera (R\&D Systems, $1 \mu \mathrm{g} /$ $\mathrm{ml}$ ) on TNF-induced proliferation in TF-1 and K562 cells showed that TNF is not causing its proliferative effects purely through induction of GM-CSF, as $90 \pm 14$ and $88 \pm 9 \%$ (means \pm S.E.M., $n=3$ ) of the $50 / \mathrm{ng} / \mathrm{ml}$ TNF-induced proliferation in $24 \mathrm{~h}$ was still present in GM-CSF-free TF-1 and K562 cells, respectively. By contrast, blocking the action of TNFR2 with an antagonistic antisera (Figure 10) rendered TF1 cells and K562 cells unable to undergo TNF-induced proliferation or TNF-induced cell death. Whereas in MOLT-4 and HL-60 cells, blocking TNFR2 with an antagonistic antisera did not influence TNF-induced apoptotic responses in either control or GM-CSF-pretreated cells. Although GM-CSF stimulates TF-1 and K562 cell proliferation and can dictate their life/death switching, the lack of GM-CSF-induced life/ death switching in MOLT- 4 and HL- 60 cells was in spite of HL60 cells proliferating to a GM-CSF pretreatment (Figure 10d).

\section{Discussion}

The induction of apoptosis in tumour cells allows killing and removal of these cells without eliciting any inflammatory response. Although TNF is known to induce apoptosis in a variety of cell types, its use in chemotherapy has been limited 

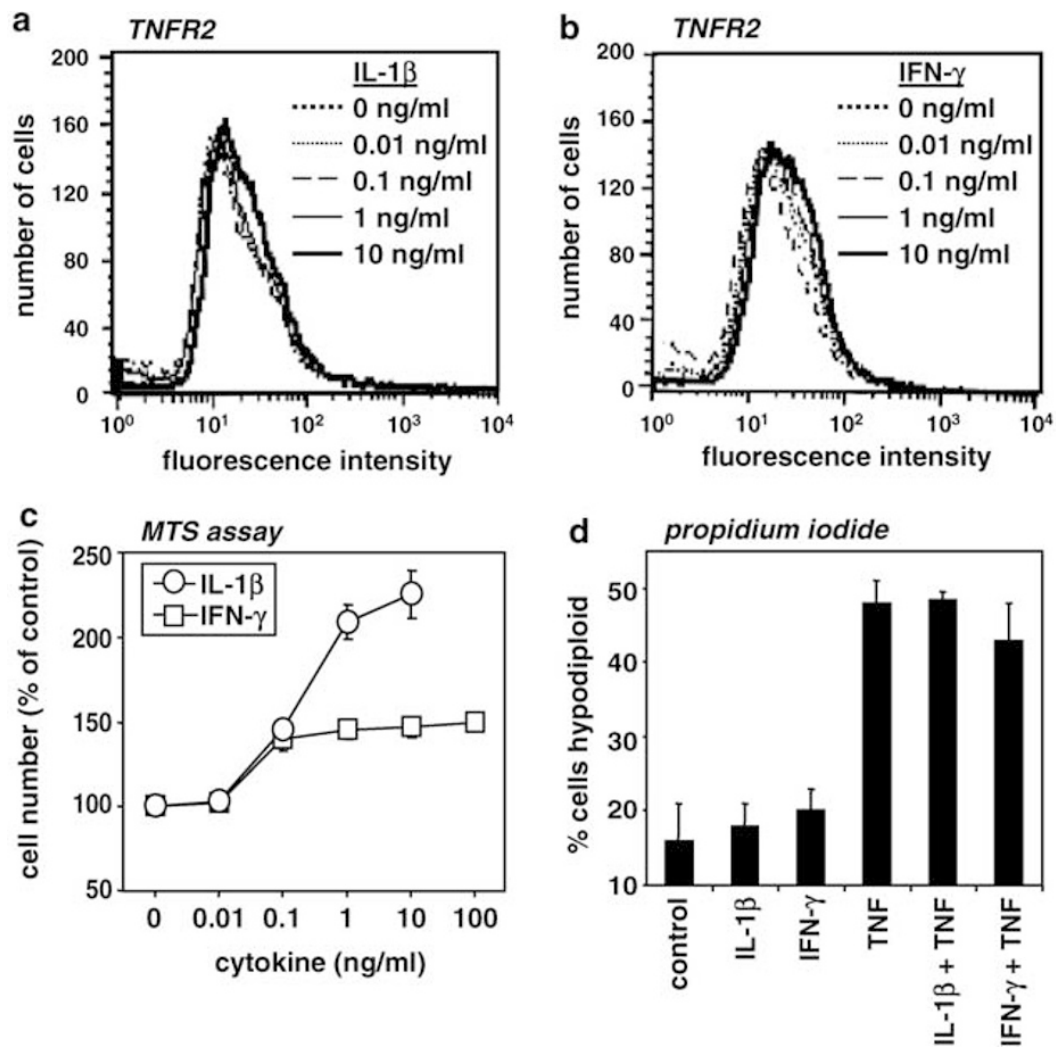

Figure 5 Effect of IL-1 $\beta$ and IFN- $\gamma$ on TF-1 cells. TNFR levels of TF-1 cells cultured in medium without GM-CSF was measured after $24 \mathrm{~h}$ exposure to (a) IL-1 $\beta$ or (b) IFN- $\gamma$ at the indicated concentration. Neither cytokine affected the expression of TNFR2. (c) Both cytokines induced concentration-dependent proliferation of the quiescent cells, according to the MTS assay, but (d) did not affect susceptibility to TNF-induced apoptosis (10 ng/ml IL-1 $\beta, 100 \mathrm{ng} / \mathrm{ml} \mathrm{IFN-} \gamma, 10 \mathrm{ng} / \mathrm{ml}$ TNF), according to propidium iodide staining. Data are the mean \pm S.D. of quadruplicate determinations from a representative experiment of three

by side effects including septic shock-like symptoms and widespread inflammation. TNF acts through binding to two different receptor types, which differ in their intracellular signalling pathways and consequent effects. TNFR1 is generally believed to be responsible for many of the deleterious effects of TNF treatment, while less is known about the effects of TNFR2. Altering the TNFR1: TNFR2 ratio may control the functional outcome of the cell after TNF binding. It was, therefore, hoped that by increasing the expression of TNFR2, the susceptibility of tumour cells to apoptosis would be increased, while reducing the deleterious effects thought to be mediated through TNFR1. Here, we have shown in certain cell types that a TNF life/death switching phenomenon occurs and the fact that these cell types are cancerous leads us to suggest that it may be possible to influence some types of cancer cells. Whether more cancer cell types also perform this life/death switching act or whether non-neoplastic cells also display this phenomenon is something that will require further investigation. However, as a strategy for the greater control of apoptotic and proliferative responses in certain subtypes of cells, the TNF life/death switching we describe here is interesting both from an academic or a therapeutic viewpoint.

TF-1 cells are human erythroleukaemic progenitor stem cells line that are stimulated by GM-CSF or IL-3. ${ }^{29}$ GM-CSF and IL-3 promote the survival and stimulate proliferation of haematopoietic cells ${ }^{30}$ and we have shown that these cytokines also had a stimulatory effect on quiescent TF-1 cells, but had no additional effect on proliferating cells. Using propidium iodide staining of hypodiploid cells and measurement of the inactive fragment of PARP DNA repair enzyme, both indicators of apoptosis, we also showed that these cytokines were antiapoptotic, as has previously been demonstrated in a variety of haematopoietic cell types. ${ }^{30-32}$

TNF also had a stimulatory effect on quiescent cells and this may have been due to TNF-induced synthesis of GM-CSF, ${ }^{33}$ which then acts in an autocrine manner to enhance proliferation. ${ }^{34}$ It is presently not clear whether just proliferation and increased TNFR2 expression in TF-1 and K562 cells is sufficient for them to be able to experience TNF life/death switching. It may be that TNF is inducing a factor other than GM-CSF to cause proliferation, a process that is sensitive to cycloheximide (Figure 8), although importantly HL-60 cells proliferate in response to GM-CSF (Figure 10) but do not then switch their TNF-responsive phenotype, suggesting a direct TNF effect on the proliferative and apoptotic machinery of cells that are able to switch. It has been demonstrated that the stimulatory effect of TNF is mediated predominantly by TNFR1, whereas TNFR2 produced only minimal proliferation. ${ }^{34}$ This was also demonstrated using TNFR-selective agents, with only TNFR1 having a similar stimulatory effect to TNF. Such an apoptotic role for TNFR2 and its lack of 

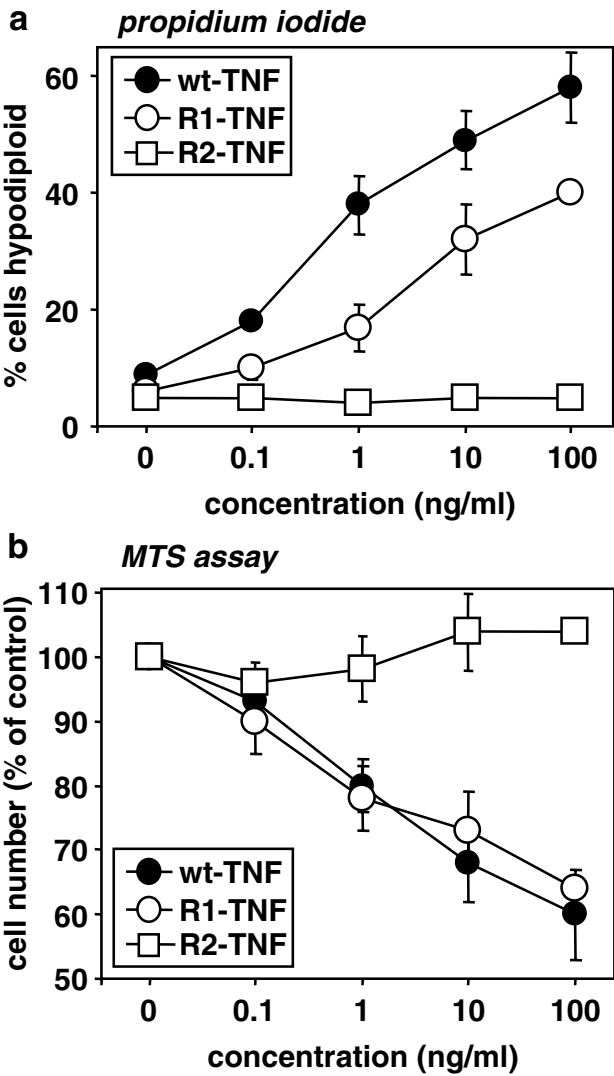

Figure 6 Effect of TNFR-selective muteins compared to TNF. When added to proliferating TF-1 cells (cultured in GM-CSF-containing medium), TNF and R1TNF $(10 \mathrm{ng} / \mathrm{ml})$ caused (a) an increase in apoptosis, according to propidium iodide staining, and (b) a similar increase in cytotoxicity, according to the MTS assay. R2-TNF mutein $(10 \mathrm{ng} / \mathrm{ml})$ had little or no effect on either apoptosis, cytotoxicity or proliferation

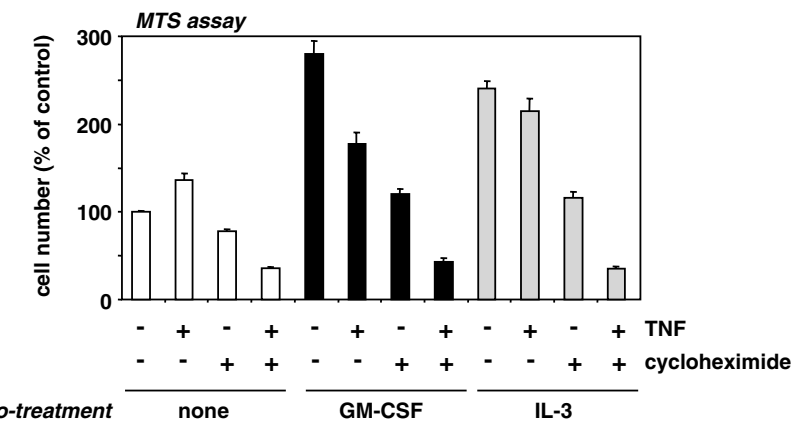

Figure 7 Proliferation of TF-1 cells by cytokines and cycloheximide. Cells cultured in medium without GM-CSF were exposed to combinations of GM-CSF $(0.1 \mathrm{ng} / \mathrm{ml}), \mathrm{IL}-3(10 \mathrm{ng} / \mathrm{ml})$, TNF $(10 \mathrm{ng} / \mathrm{ml})$ and cycloheximide $(1 \mu \mathrm{g} / \mathrm{ml})$. After $24 \mathrm{~h}$ exposure, cells were assayed for metabolic activity (related to viable cell number) using the MTS assay. Data are the mean +S.D. of quadruplicate determinations from a representative independent experiment, repeated at least two other times with similar findings

involvement in the proliferative effects of TNF is against some of the current thinking, which suggests that TNFR1 is purely apoptotic in nature and TNFR2 acts only to cause proliferation. Here, we see that there is a role for TNFR2 in the life/
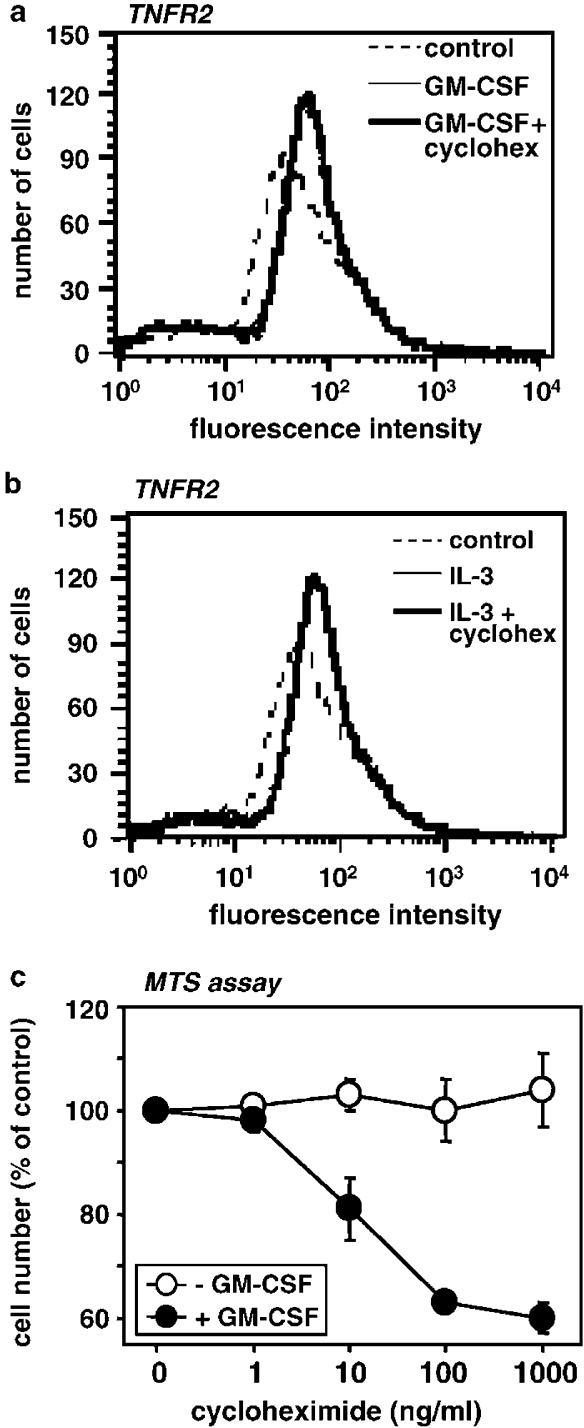

Figure 8 Effect of cycloheximide on TF-1 cells. Cells cultured in medium without GM-CSF were exposed to (a) GM-CSF $(0.1 \mathrm{ng} / \mathrm{ml})$ or $(\mathbf{b}) \mathrm{IL}-3(10 \mathrm{ng} / \mathrm{ml})$, with or without simultaneous addition of cycloheximide $(1 \mu \mathrm{g} / \mathrm{ml})$. After $24 \mathrm{~h}$ exposure, the level of TNFR expression was measured and analysed by FACS. The increase in TNFR2 induced by GM-CSF or IL-3 was unaffected by cycloheximide (GM-CSF/IL-3 alone is underneath thick line). Data are from a representative independent experiment performed at least two other times with similar findings. (c) Cells cultured in medium with (closed symbols) and without (open symbols) GM-CSF (proliferating and quiescent cells, respectively) were exposed to cycloheximide at the indicated concentration and viable cell number was measured using the MTS assay. Quiescent cells were unaffected by concentrations up to $1 \mu \mathrm{g} / \mathrm{ml}$, whereas the total number of proliferating cells was decreased

death switching phenomenon in these cells and is certainly co-operative in purpose although understanding its exact nature will require further investigation.

We have shown that GM-CSF and IL-3 enhanced the ability of TNF to induce apoptosis. As these growth factors induce proliferation in the quiescent cells, it was possible that this explained the increased susceptibility to TNF-induced apoptosis. However, previous studies have shown that using cytokines to recruit leukaemia cells into cell cycle, and thus 

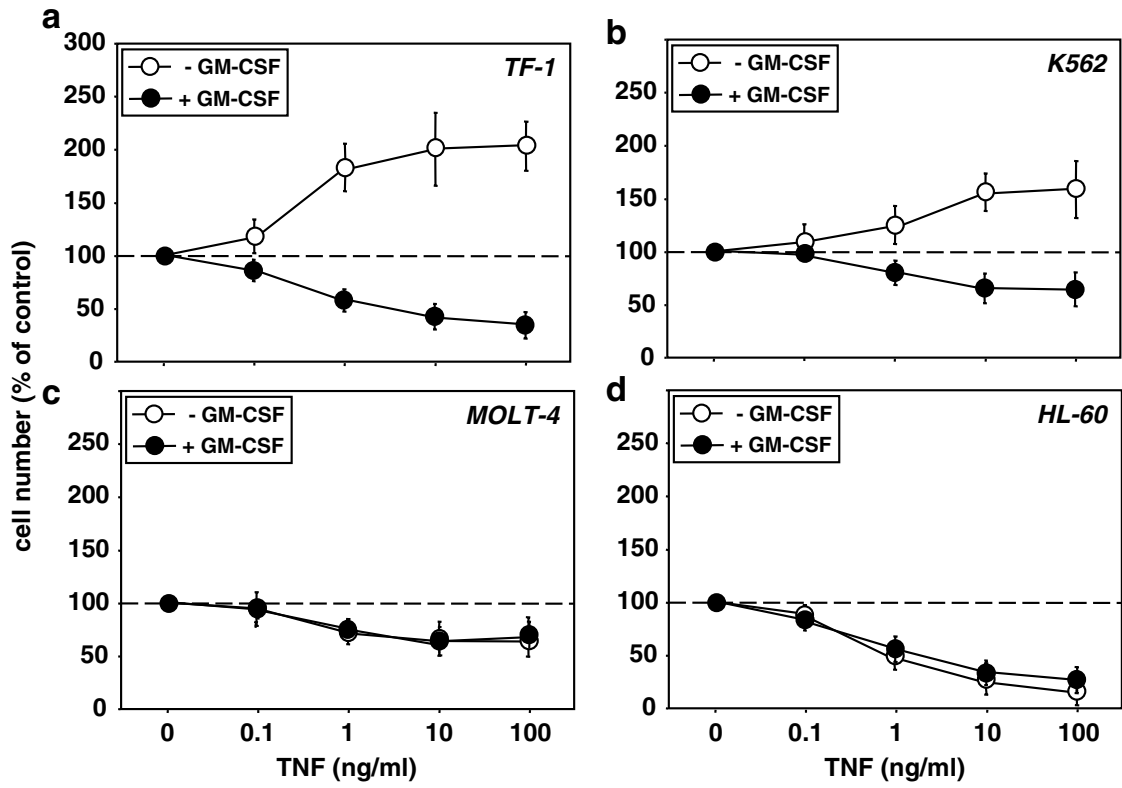

Figure 9 TNF life/death switching in human leukaemia cells. TNF concentration-response relationships of human TF-1 (a), K562 (b), MOLT-4 (c) or HL-60 (d) cells that were preincubated in medium without (open symbols) or with $1 \mathrm{ng} / \mathrm{ml} \mathrm{GM-CSF}$ (closed symbols) for $24 \mathrm{~h}$ before exposure to the indicated concentration of TNF for a further $24 \mathrm{~h}$. Cell number was assessed by the MTS assay as described in the Materials and Methods section. Values represent the means \pm S.E.M. of at least three independent determinations. GM-CSF-free values are normalised to the values from GM-CSF-free control cells, whereas values from cells exposed to GM-CSF preincubation are normalised to their control cells, which have also seen GM-CSF during the preincubation step

make them more susceptible to chemotherapy, have revealed no benefit and it has been suggested that IL-3 and GM-CSF may even protect cells in vitro from chemotherapy-induced agents. ${ }^{28}$ We have also shown that other cytokines (IL-1 $\beta$ and IFN- $\gamma$ ), which have stimulatory effects on quiescent TF- 1 cells, had no effect on TNF-induced apoptosis. These latter cytokines had little or no effect on the expression of either TNF receptor, whereas GM-CSF and IL-3 both increased the expression of TNFR2, but not TNFR1, as has also been previously demonstrated. ${ }^{8,27}$ It is therefore possible that the increased levels of TNFR2 may be responsible for the increased susceptibility to apoptosis.

It has been demonstrated that TNF-induced apoptosis was mimicked by a TNFR1-stimulating antibody, and was almost completely blocked by a TNFR1-blocking antisera, whereas anti-TNFR2 antisera had only a marginal effect. ${ }^{21,35}$ Selective activation of TNFR1 also elicited a full cytotoxic response in leukaemia cells, ${ }^{36}$ and apoptotic response in primary cytotrophoblasts. ${ }^{37}$ TNFR2 had little effect in both of these cell types. Berger et al. ${ }^{17}$ also showed that TNF-induced apoptosis was mediated preferentially by TNFR1 and suggested that upregulation of TNFR1 expression may be a mechanism for sensitising tumour cells to the effects of TNF leading to haemorrhagic necrosis. Similarly, we have demonstrated here that the TNFR1-specific stimulation had an almost identical toxic effect on proliferating cells to TNF, whereas stimulation of TNFR2 alone had little or no effect (Figure 6). However, wild-type TNF appeared to have a greater effect than R1-TNF in inducing apoptosis (according to propidium iodide staining), with R2-TNF again having no effect. This may indicate that the full apoptotic effect of TNF required stimulation of both TNFR1 and TNFR2. Although TNFR2 alone may not able to induce any effect, it may enhance the effects and signalling of TNFR1. TNFR1-specific muteins, but not TNFR2-specific muteins have also been shown to induce NF- $\kappa$ B activation. ${ }^{38,39}$ Whereas both soluble and membrane-bound TNF have comparable bioactivities when acting on TNFR1, membrane-bound TNF is the prime activating ligand for TNFR2. ${ }^{40}$ The membrane-bound form of TNF can also trigger effective cytotoxicity by stimulating TNFR2 ${ }^{41}$ It is therefore likely that the effect of TNFR2 activation has been experimentally underestimated here and in other systems.

Although it has been suggested that proapoptotic signals are mediated via TNFR1 and antiapoptotic signals are mediated via TNFR2 in dendritic cells, ${ }^{42}$ under certain circumstances the two classes of TNF receptors cooperate with each other to produce enhanced cellular responses. It is possible that TNFR2 may enhance TNFR1-induced apopto$\mathrm{sis}^{43}$ and it has also been shown that induced TNFR2 expression in the presence of membrane-bound TNF and TNFR1 results in lymphocyte cell death. ${ }^{44}$ TNFR2 may also induce toxicity in some cell types as well as potentiating TNFR1-mediated toxic responses. ${ }^{45-47}$ Overexpression of TNFR2 can result in the enhancement of TNFR1-mediated signalling. ${ }^{48}$ When overexpressed, TNFR2 can mediate apoptosis, NF- $\kappa \mathrm{B}$ activation and $\mathrm{c}$-Jun $\mathrm{N}$-terminal kinase (JNK) activation, ${ }^{47,49}$ whereas TNFR1 can mediate similar signals without overexpression. ${ }^{6}$ Thus, although TNFR1 is clearly the primary receptor for TNF's apoptotic responses, TNFR2 may have an ancillary role to modulate TNFR1's actions. This is also supported here in the evidence that TF-1 and K562 cells require effective activity in order for both the proliferative and apoptotic effects of TNF to become apparent as incubation with an anti-TNFR antisera blocks TNF responses in these cell types. Blockade of TNFR2 with 


\begin{tabular}{|l|}
\hline no GM-CSF \\
pretreatment \\
GM-CSF \\
pretreated
\end{tabular}
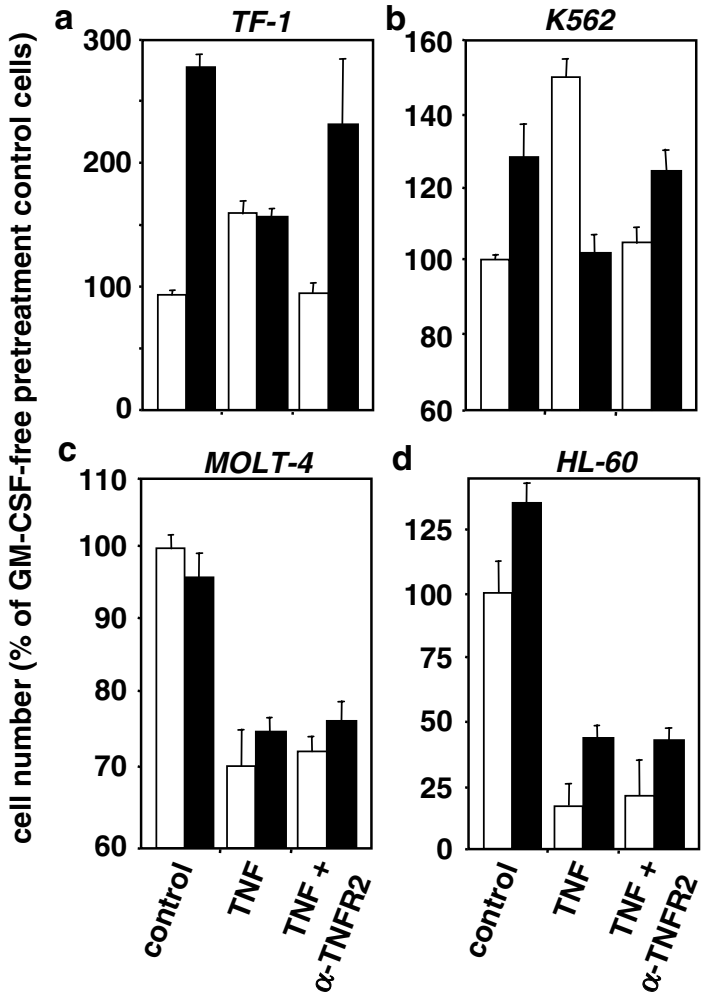

Figure 10 Role of TNFR2 in TNF life/death switching in human leukaemia cells. Human TF-1 (a), K562 (b), MOLT-4 (c) or HL-60 (d) cells that were preincubated in medium without (open symbols) or with $1 \mathrm{ng} / \mathrm{ml} \mathrm{GM}-\mathrm{CSF}$ (closed symbols) for $24 \mathrm{~h}$ were treated with $50 \mathrm{ng} / \mathrm{ml}$ TNF. Cell number was assessed $24 \mathrm{~h}$ later by the MTS assay as described in the Materials and Methods section. Values represent the means + S.E.M. of at least three independent determinations. All values are normalised to the control cell levels seen in cells in GM-CSFfree conditions, so as to indicate the effect of the GM-CSF-preincubation step on relative cell numbers

antagonistic antisera does not influence TNF-induced cell death of MOLT-4 and HL-60 cells, which only respond to TNF by undergoing cytotoxicity, displaying no TNF life/death switching. Presumably TNFR1 function in these cell types predominates with no modulatory effects of TNFR2 apparent.

A potential ligand-passing role for TNFR2 was proposed by Tartaglia et $a{ }^{50}{ }^{50}$ in which TNFR2 acts to bind TNF with high affinity and increase the local microenvironment of TNF ligand surrounding the TNFR1 receptor, which then activates intracellular apoptotic signalling. Heterocomplexes of TNFR1 and TNFR2 have been observed which support such a ligandpassing mode of TNFR2 function. ${ }^{51}$ Such a ligand-passing role for TNFR2 may be responsible here in the observed enhancement of TNF-stimulated apoptosis in GM-CSFswitched TF-1 cells, since raised TNFR2 levels correlate with the apoptotic phenotype, but TNFR2 stimulation by itself does not mediate cell death. However, the function of TNFR2 is necessary in TF-1 and K562 cell TNF life/death responses as shown here with antagonistic antisera. This again supports a possible ligand-passing role of TNFR2 in life/death switching. However, the cooperativity of TNFR1 and TNFR2 in life/death switching may occur not at the level of the ligand but at the level of their intracellular signalling, as has been suggested by others. ${ }^{48,51-54}$ The notion of ligand-passing by TNFR2 seems to be less favoured now by researchers and clearly more work needs to be performed to properly understand the mechanisms of TNFR2-enhancement of TNFR1 responses.

Stimulation of TNFR1 can trigger such opposing cellular responses as antiapoptotic NF- $\kappa \mathrm{B}$ activation and induction of apoptosis within the same cell. ${ }^{52}$ Activation of the transcription factor $\mathrm{NF}-\kappa \mathrm{B}$, and subsequent induction of protective proteins, is involved in TNF-induced cell survival ${ }^{55}$ and can protect against TNF-induced apoptosis. Thus, it has been proposed that the balance between life and death is regulated by $\mathrm{NF}-\kappa \mathrm{B} .{ }^{25}$ The pathway which is initially chosen may depend on the presence or absence of low constitutive NF- $\kappa \mathrm{B}$ activation. Inhibition of the induction of NF- $\kappa$ B sensitises cells to TNF-induced toxicity, ${ }^{56}$ and inhibition of protein synthesis appears to have a similar effect. We have shown that the protein-synthesis inhibitor, cycloheximide, sensitised TF-1 cells to TNF-induced toxicity, and this was most likely by preventing induction of protective or survival factors. ${ }^{57}$ Unlike the proliferative responses, TF-1 apoptosis probably does not require protein synthesis as apoptosis occurred in the presence of cycloheximide (Figure 6). Moreover, GM-CSF or IL-3 induction of TNFR2 still persisted with cycloheximide present. It may be that TNFR2 induction may be less sensitive to cycloheximide or that there is a presynthesised pool of TNFR2 that is unaffected by cycloheximide that is still exhibited through GM-CSF or IL-3 treatment. Either way, cycloheximide allowed only the apoptotic responses of TNF to be demonstrated. It may also be that instead of GM-CSF or IL-3 causing the switching from a proliferative to a death phenotype, TNF-induced proliferation may still occur after GM-CSF pretreatment, but GM-CSF may signal a TNFapoptotic pathway to be revealed that outweighs any TNF proliferative responses.

\section{Materials and Methods}

\section{Materials}

All tissue culture reagents were from Invitrogen Ltd., Paisley, UK. Recombinant human cytokines were purchased from R\&D Systems, Abingdon, UK. GM-CSF was a generous gift from Dr. Meenu Wadhwa (NIBSC, Potter's Bar, UK). TNFR1- and TNFR2-selective mutant proteins ('muteins') R1-TNF and R2-TNF, respectively, were as previously described. $^{8,58}$ TNFR monoclonal antisera htr-9 (TNFR1) and utr-1 (TNFR2) were from Bachem Ltd., Merseyside, UK. Antagonistic monoclonal TNFR2-specific antisera (Genzyme Corporation) was as described previously. ${ }^{8}$ All other reagents were purchased from SigmaAldrich Company, Dorset, UK and were of the highest grade available.

\section{Cells}

TF-1 human erythroleukaemic cells were purchased from ECACC (cell no. 93022307). Cultures of TF-1 cells were maintained in RPMI 1640 medium containing $100 \mathrm{U} / \mathrm{ml}$ penicillin, $100 \mu \mathrm{g} / \mathrm{ml}$ streptomycin, $5 \%$ foetal bovine serum (FBS) and $0.1 \mathrm{ng} / \mathrm{ml}$ human recombinant GM-CSF. Cells were 
washed and resuspended in medium with or without GM-CSF, counted and plated onto 96 -well plates at a density of $2 \times 10^{5} \mathrm{celll} / \mathrm{ml}$ or 12 -well plates at $1 \times 10^{5} \mathrm{cell} / \mathrm{s} / \mathrm{ml}$. Plates were incubated overnight in a gas phase of $5 \% \mathrm{CO}_{2}$ at $37^{\circ} \mathrm{C}$ before adding cytokines. K562 human chronic myelogenous leukaemia cells, MOLT-4 human acute T-lymphocytic leukaemia cells and HL-60 human promyelocytic leukaemia cells were generously donated by Dr. Heather Wallace (University of Aberdeen) and were cultured as for TF-1 cells except that their RPMI 1640 medium was not supplemented with GM-CSF.

\section{TNFR expression measurement}

Cells were washed and then resuspended in serum-free medium. A $200 \mu \mathrm{l}$ aliquot was incubated on ice for $1 \mathrm{~h}$ in a 1:50 dilution of mouse antihuman TNFR1 or TNFR2 primary antibody (or neither for control assessments). Cells were centrifuged $(1000 \times g, 5 \mathrm{~min})$ and then resuspended again in $200 \mu \mathrm{l}$ serum-free medium with a 1:50 dilution of fluorescein isothiocyanate (FITC)-labelled anti-mouse antibody (Diagnostics Scotland, Edinburgh, UK) for $30 \mathrm{~min}$ on ice. Prior to fluorescenceactivated cell sorting (FACS) analysis, the cells were washed three times in PBS $+2 \%$ FBS. FACS analysis was performed on a Becton Dickinson FACScaliber according to the manufacturer's protocols.

\section{MTS cytotoxicity/proliferation assay}

Cytokines were added to TF-1 cells in 96-well plates and incubated for 4 or $24 \mathrm{~h}$. After this period, $40 \mu \mathrm{l}$ CellTiter $96{ }^{\mathrm{R}}$ Aqueous One Solution (MTS; Promega, Southampton, UK) was added to each well and incubated at $37^{\circ} \mathrm{C}$ for $1 \mathrm{~h}$ before measuring the absorbance at $540 \mathrm{~nm}$ on a Molecular Devices platereader, blanking on a cell-free well.

\section{Apoptosis assays}

\section{Propidium iodide staining}

Cells in 12-well plates were incubated with cytokines for 4 or $24 \mathrm{~h}$. The cells were then washed with phosphat-buffered saline (PBS) and fixed with $70 \%$ ethanol. Propidium iodide $(10 \mathrm{mg} / \mathrm{ml})$ and RNase $(1 \mathrm{mg} / \mathrm{ml})$ were added to cells and incubated at room temperature for $30 \mathrm{~min}$. Cells were washed again with PBS and the cells analysed by FACS for measurement of cell cycle and DNA hypodiploidicy and fragmentation.

\section{Annexin V Binding}

Cells were washed with PBS and resuspended in binding buffer and Annexin V (Caltag MedSystems, Towcester, UK) in the dark for $10 \mathrm{~min}$. Cells were then washed with PBS and resuspended in PBS for FACS analysis.

\section{PARP fragment assay}

Cells were washed twice with 1\% FBS in PBS and fixed for 10 min in $4 \%$ paraformaledhyde in PBS. Cells were washed in PBS containing $0.1 \%$ sodium azide and $1 \%$ FBS, then twice with PBS containing $0.1 \%$ sodium azide, $1 \%$ FBS and $0.1 \%$ saponin (ICPerm). Cells were resuspended in ICPerm with FITC-labelled $85 \mathrm{kDa}$ PARP fragment antibody (BioSource International, Belgium) for $30 \mathrm{~min}$ on ice. Cells were washed twice with ICPerm and once with PBS before resuspending in PBS for FACS analysis.

\section{Acknowledgements}

We thank Drs. Meenu Wadhwa, Peter Vandenabeele and Heather Wallace for reagents and cells. This work was supported by the Scottish Hospitals Endowment Research Trust and the Association for International Cancer Research.

\section{References}

1. Old LJ (1985) Tumor necrosis factor (TNF). Science 230: 630-632

2. Carswell EA, Old LJ, Kassel RL, Green S, Fiore N and Williamson B (1975) An endotoxin-induced serum factor that causes necrosis of tumours. Proc. Natl. Acad. Sci. USA 72: 3666-3670

3. Fiers W (1991) Tumor-necrosis-factor - characterization at the molecular, cellular and in vivo level. FEBS Lett. 285: 199-212

4. Kelley J (1990) Cytokines of the lung. Am. Rev. Respir. Dis. 141: 765-788

5. Vandenabeele P, Declercq W, Beyaert R and Fiers W (1995) 2 Tumornecrosis-factor receptors - structure and function. Trends Cell Biol. 5: 392-399

6. MacEwan DJ (2002) TNF receptor subtype signaling. Differences and cellular consequences. Cell. Signal. 14: 477-492

7. Locksley RM, Killeen N and Lenardo MJ (2001) The TNF and TNF receptor superfamilies: integrating mammalian biology. Cell 104: 487-501

8. Baxter GT, Kuo RC, Jupp OJ, Vandenabeele P and MacEwan DJ (1999) Tumor necrosis factor- $\alpha$ mediates both apoptotic cell death and cell proliferation in a human hematopoietic cell line dependent on mitotic activity and receptor subtype expression. J. Biol. Chem. 274: 9539-9547

9. Tsuru K, Horikawa T, Budiyanto A, Hikita I, Ueda M and Ichihashi M (2001) Low-dose ultraviolet $b$ radiation synergizes with TNF- $\alpha$ to induce apoptosis of keratinocytes. J. Dermatol. Sci. 26: 209-216

10. Kuo KW, Hsu SH, Li YP, Lin WL, Liu LF, Chang LC, Lin CC, Lin CN and Sheu HM (2000) Anticancer activity evaluation of the solanum glycoalkaloid solamargine - triggering apoptosis in human hepatoma cells. Biochem. Pharmacol. 60: 1865-1873

11. Messmer UK, Briner VA and Pfeilschifter J (2000) Basic fibroblast growth factor selectively enhances TNF- $\alpha$ - induced apoptotic cell death in glomerular endothelial cells: effects on apoptotic signaling pathways. J. Am. Soc. Nephrol. 11: 2199-2211

12. Hsu SH, Tsai TR, Lin CN, Yen MH and Kuo KW (1996) Solamargine purified from solanum incanum Chinese herb triggers gene expression of human TNFR I which may lead to cell apoptosis. Biochem. Biophys. Res. Commun. 229: 1-5

13. Hannun YA (1997) Apoptosis and the dilemma of cancer chemotherapy. Blood 89: $1845-1853$

14. Wyllie AH (1993) Apoptosis (the 1992 Rose, Frank memorial lecture. Br. J. Cancer 67: 205-208

15. Saikumar P, Dong Z, Mikhailov V, Denton M, Weinberg JM and Venkatachalam MA (1999) Apoptosis: definition, mechansisms, and relevance to disease. Am. J. Dis. 107: 489-506

16. Tsushima H, Imaizumi Y, Imanishi D, Fuchigami K and Tomonaga I (1999) Fas antigen (CD95) in pure erythroid cell line AS-E2 is induced by interferongamma and tumor necrosis factor- $\alpha$ and potentiates apoptotic death. Exp. Hematol. 27: 433-440

17. Berger AC, Alexander HR, Wu PC, Tang GQ, Gnant MFX, Mixon A, Turner ES and Libutti SK (2000) Tumour necrosis factor receptor I (p55) is upregulated on endothelial cells by exposure to the tumour-derived cytokine endothelial monocyte-activating polypeptide II (EMAP-II). Cytokine 12: 992-1000

18. Rusten LS and Jacobsen SEW (1995) Tumor-necrosis-factor (TNF)- $\alpha$ directly inhibits human erythropoiesis in-vitro - role of p55 and p75 TNF receptors. Blood 85: 989-996

19. Rebel VI, Hartnett S, Hill GR, Lazo-Kallanian SB, Ferrara JLM and Sieff CA (1999) Essential role for the p55 tumor necrosis factor receptor in regulating hematopoiesis at a stem cell level. J. Exp. Med. 190: 1493-1503

20. Delwel R, Vanbuitenen C, Lowenberg B and Touw I (1992) Involvement of tumor-necrosis-factor (TNF) receptors p55 and p75 in TNF responses of acute myeloid-leukemia blasts in vitro. Blood 80: 1798-1803

21. Hu XT, Tang MQ, Fisher AB, Olashaw N and Zuckerman KS (1999) TNF- $\alpha-$ induced growth suppression of CD34(+) myeloid leukemic cell lines signals 
through TNF receptor type I and is associated with NF- $\kappa$ B activation. J. Immunol. 163: 3106-3115

22. Carter A, Haddad N, Draxler I, Israeli E, Raz B and Rowe JM (1996) Expression and role in growth regulation of tumour necrosis factor receptors p 55 and $p 75$ in acute myeloblastic leukaemia cells. Br. J. Haematol. 92: 116-126

23. Berkova N, Lemay A, Korobko V, Shingarova L, Sagaidak $L$ and Goupil $S$ (1999) Tumor necrosis factor mutants with selective cytotoxic activity. Cancer Detect. Prev. 23: 1-7

24. Vanostade X, Vandenabeele P, Everaerdt B, Loetscher H, Gentz R, Brockhaus M, Lesslauer W, Tavernier J, Brouckaert P and Fiers W (1993) Human TNF mutants with selective activity on the p55 receptor. Nature 361: 266-269

25. Martinon F, Holler N, Richard C and Tschopp J (2000) Activation of a pro-apoptotic amplification loop through inhibition of NF- $\kappa$ B-dependent survival signals by caspase-mediated inactivation of RIP. FEBS Lett. 468 : 134-136

26. Avanzi GC, Porcu P, Brizzi MF, Ghigo D, Bosia A and Pegoraro L (1991) Interleukin 3-dependent proliferation of the human MO-7e cell-line is supported by discrete activation of late G1 genes. Cancer Res. 51: 1741-1743

27. Williams MA, Newland AC and Kelsey SM (2000) Cytokine modulated cellmembrane bound tumour necrosis factor expression is associated with enhanced monocyte-mediated killing of human leukaemic targets. Leuk. Res. 24: $317-330$

28. Hassan HT and Zander AR (1997) Haematopoietic cytokines in the biology and treatment of acute myeloid leukaemia: perspectives and controversies. Oncol. Rep. 4: 1141-1149

29. Kitamura T, Tange T, Terasawa T, Chiba S, Kuwaki T, Miyagawa K, Piao YF Miyazono K, Urabe A and Takaku F (1989) Establishment and characterization of a unique human cell-line that proliferates dependently on GM-CSF, IL-3, or erythropoietin. J. Cell. Physiol. 140: 323-334

30. Klampfer L, Zhang J and Nimer SD (1999) GM-CSF rescues TF-1 cells from growth factor withdrawal-induced, but not differentiation-induced apoptosis: the role of bcl-2 and mcl-1. Cytokine 11: 849-855

31. Murray J, Barbara JAJ, Dunkley SA, Lopez AF, Vanostade X, Condliffe AM, Dransfield I, Haslett C and Chilvers ER (1997) Regulation of neutrophil apoptosis by tumor necrosis factor- $\alpha$ : requirement for TNFR5 5 and TNFR7 5 for induction of apoptosis in vitro. Blood 90: 2772-2783

32. Wong CK, Zhang JP, Lam CWK, Ho CY and Hjelm NM (1999) Opposing effects of sodium salicylate and haematopoietic cytokines IL-3, IL-5 and GM-CSF on mitogen-activated protein kinases and apoptosis of EOL-1 cells. Immunol. Invest. 28: 365-379

33. Quentmeier H, Dirks WG, Fleckenstein D, Zaborski M and Drexler HG (2000) Tumor necrosis factor- $\alpha$-induced proliferation requires synthesis of granulocyte-macrophage colony-stimulating factor. Exp. Hematol. 28: 1008-1015

34. Wadhwa M, Dilger P, Meager A, Walker B, Gainesdas R and Thorpe R (1996) IL-4 and TNF- $\alpha$-mediated proliferation of the human megakaryocytic line $\mathrm{M}-\mathrm{O} 7 \mathrm{e}$ is regulated by induced autocrine production of GM-CSF. Cytokine 8 : 900-909

35. Horie T, Dobashi K, lizuka K, Yoshii A, Shimizu Y, Nakazawa T and Mori M (1999) Interferon-gamma rescues TNF- $\alpha$-induced apoptosis mediated by upregulation of TNFR2 on EOL-1 cells. Exp. Hematol. 27: 512-519

36. Loetscher H, Stueber D, Banner D, Mackay F and Lesslauer W (1993) Human tumor-necrosis-factor- $\alpha$ (TNF- $\alpha$ ) mutants with exclusive specificity for the 55 kDa or 75-kDa TNF receptors. J. Biol. Chem. 268: 26350-26357

37. Yui J, Hemmings D, Garcialloret M and Guilbert LJ (1996) Expression of the human p55 and p75 tumor necrosis factor receptors in primary villous trophoblasts and their role in cytotoxic signal transduction. Biol. Reprod. 55: 400-409

38. Jelkmann W and Hellwig-Buergel T (1999) Tumor necrosis factor p55 receptor (TNF-RI) mediates the in vitro inhibition of hepatic erythropoietin production. Exp. Hematol. 27: 224-228

39. McFarlane SM, Pashmi G, Connell MC, Littlejohn AF, Tucker SJ Vandenabeele $P$ and MacEwan DJ (2002) Differential activation of nuclear factor- $\kappa \mathrm{B}$ by tumour necrosis factor receptor subtypes. TNFR1 predominates whereas TNFR2 activates transcription poorly. FEBS Lett. 515: $119-126$

40. Grell M, Douni E, Wajant H, Lohden M, Clauss M, Maxeiner B, Georgopoulos S, Lesslauer W, Kollias G, Pfizenmaier K and Scheurich P (1995) The transmembrane form of tumor-necrosis-factor is the prime activating ligand of the $80 \mathrm{kDa}$ tumor-necrosis-factor receptor. Cell 83: 793-802

41. Wallach D, Varfolomeev EE, Malinin NL, Goltsev YV, Kovalenko AV and Boldin MP (1999) Tumor necrosis factor receptor and Fas signaling mechanisms. Annu. Rev. Immunol. 17: 331-367

42. Funk JO, Walczak H, Voigtlander C, Berchtold S, Baumeister T, Rauch P, Rossner S, Steinkasserer A, Schuler G and Lutz MB (2000) Cutting edge: resistance to apoptosis and continuous proliferation of dendritic cells deficient for TNF receptor-1. J. Immunol. 165: 4792-4796

43. Lung HL, Leung KN, Stadlin A, Ma CM and Tsang D (2001) Induction of tumor necrosis factor receptor type 2 gene expression by tumor necrosis factor- $\alpha$ in rat primary astrocytes. Life Sci. 68: 2081-2091

44. Sipe KJ, Dantzer R, Kelley KW and Weyhenmeyer JA (1998) Expression of the $75 \mathrm{kDa}$ TNF receptor and its role in contact-mediated neuronal cell death. Mol. Brain Res. 62: 111-121

45. Bigda J, Beletsky I, Brakebusch C, Varfolomeev Y, Engelmann H, Bigda J, Holtmann $\mathrm{H}$ and Wallach D (1994) Dual role of the p75 tumor-necrosis-factor (TNF) receptor in TNF cytotoxicity. J. Exp. Med. 180: 445-460

46. Medvedev AE, Sundan A and Espevik T (1994) Involvement of the tumornecrosis-factor receptor p75 in mediating cytotoxicity and gene regulating activities. Eur. J. Immunol. 24: 2842-2849

47. Jupp OJ, McFarlane SM, Anderson HM, Littlejohn AF, Mohamed AAA, MacKay $\mathrm{RH}$, Vandenabeele $\mathrm{P}$ and MacEwan DJ (2001) Type II tumour necrosis factor- $\alpha$ receptor (TNFR2) activates c-Jun N-terminal kinase (JNK) but not mitogenactivated protein kinase (MAPK) or p38 MAPK pathways. Biochem. J. 359: $525-535$

48. Vandenabeele P, Declerq W, Vercammen D, Van de Craen M, Grooten J, Loetscher H, Brockhaus M, Lesslauer W and Fiers W (1992) Functional characterization of the human tumor necrosis factor receptor p75 in a transfected rat/mouse T cell hybridoma. J. Exp. Med. 176: 1015

49. Haridas V, Darnay BG, Natarajan K, Heller R and Aggarwal BB (1998) Overexpression of the p80 TNF receptor leads to TNF-dependent apoptosis, nuclear factor- $\kappa \mathrm{B}$ activation, and c-Jun kinase activation. J. Immunol. 160: 3152-3162

50. Tartaglia LA, Pennica D and Goeddel DV (1993) Ligand passing - the $75-\mathrm{kDa}$ tumor-necrosis-factor (TNF) receptor recruits TNF for signaling by the $55-\mathrm{kDa}$ TNF receptor. J. Biol. Chem. 268: 18542-18548

51. Pinckard JK, Sheehan KCF and Schreiber RD (1997) Ligand-induced formation of p55 and p75 tumor necrosis factor receptor heterocomplexes on intact cells. J. Biol. Chem. 272: 10784-10789

52. Wajant $H$ and Scheurich $P(2001)$ Tumor necrosis factor receptor-associated factor (TRAF) 2 and its role in TNF signaling. Intl. J. Biochem. Cell Biol. 33: 19-32

53. Fotin-Mleczek M, Henkler F, Samel D, Reichwein M, Hausser A, Parmryd I, Scheurich P, Schmid JA and Wajant $\mathrm{H}$ (2002) Apoptotic crosstalk of TNF receptors: TNF-R2-induces depletion of TRAF2 and IAP proteins and accelerates TNF-R1-dependent activation of caspase-8. J. Cell. Sci. 115: 2757-2770

54. Krippner-Heidenreich A, Tubing F, Bryde S, Willi S, Zimmermann G and Scheurich $P(2002)$ Control of receptor-induced signaling complex formation by the kinetics of ligand/receptor interaction. J. Biol. Chem. 277: 44155-44163

55. Liu RY, Fan C, Olashaw NE, Wang X and Zuckerman KS (1999) Tumor necrosis factor- $\alpha$-induced proliferation of human $\mathrm{MO7e}$ leukemic cells occurs via activation of nuclear factor $\kappa \mathrm{B}$ transcription factor. J. Biol. Chem. 274: 13877-13885

56. Duffey DC, Crowl-Bancroft CV, Chen Z, Ondrey FG, Nejad-Sattari M, Dong G and Van Waes $C(2000)$ Inhibition of transcription factor nuclear factor- $k B$ by a mutant inhibitor- $\kappa \mathrm{B} \alpha$ attenuates resistance of human head and neck squamous cell carcinoma to TNF- $\alpha$ caspase-mediated cell death. Br. J. Cancer 83: 1367-1374

57. Schulz A and Bauer G (2000) Selective effect of tumor necrosis factor on transformed versus nontransformed cells: nonselective signal recognition but differential target cell response. Anticancer Res. 20: 3435-3442

58. Jupp OJ, Vandenabeele P and MacEwan DJ (2003) Distinct regulation of cytosolic phospholipase A2 phosphorylation, translocation, proteolysis and activation by tumour necrosis factor-receptor subtypes. Biochem. J. 374: 453-461 